Annals of Warsaw University of Life Sciences - SGGW

Land Reclamation No 46 (1), 2014: 33-42

(Ann. Warsaw Univ. Life Sci. - SGGW, Land Reclam. 46 (1), 2014)

\title{
Hydraulic performance of zero-valent iron and nano-sized zero-valent iron permeable reactive barriers - laboratory test
}

\author{
JOANNA FRONCZYK, KATARZYNA PAWLUK \\ Department of Geotechnical Engineering, Warsaw University of Life Sciences - SGGW
}

\begin{abstract}
Hydraulic performance of zero-valent iron and nano-sized zero-valent iron permeable reactive barriers - laboratory test. The hydraulic conductivity of zero-valent iron treatment zone of permeable reactive barriers (PRBs) may be decreased by reducing the porosity caused by gas production and solids precipitation. The study was undertaken in order to evaluate the influence of chloride and heavy metals on the hydraulic conductivity of ZVI and nZVI using hydraulic conductivity tests as well as continuous column tests. Results show that the lead retention in the solution had no impact for hydraulic conductivity in ZVI sample, on the other hand the calculated hydraulic conductivity losses in nZVI sample (from $4.10 \cdot 10^{-5}$ to $2.30 \cdot 10^{-5} \mathrm{~m} \cdot \mathrm{s}^{-1}$ ) were observed. Results also indicate that liquids containing the mixture of heavy metals may cause significant decrease in hydraulic conductivity (from $1.03 \cdot 10^{-4}$ to $1.51 \cdot 10^{-6} \mathrm{~m} \cdot \mathrm{s}^{-1}$ ). During the column tests, several number of clogging of the reactive material caused by iron hydroxides precipitation was observed over the course of injection of heavy metals solution. In contrast, the hydraulic conductivity of ZVI and nZVI is unaffected when they are permeated with chloride ions solution $\left(k=1.03 \cdot 10^{-4} \mathrm{~m} \cdot \mathrm{s}^{-1}\right)$. Finally, the results indicate the need to take account of changes in the hydraulic conductivity of reactive materials for successful implementation of PRBs technology.
\end{abstract}

Key words: permeable reactive barriers, hydraulic conductivity, zero-valent iron, nano-sized zero-valent iron

\section{INTRODUCTION}

Permeable reactive barriers (PRBs) are commonly used in groundwater remediation. This in-situ method enhance natural attenuation processes occurring in contaminated groundwater (Gavaskar et al.2000). There are numbers of reactive materials filling PRBs, including: zero-valent iron (Tratnyek et al. 2003; Dries et al. 2005; Johnson et al. 2008), oxygen releasing compounds - ORCs (Kao et al. 2001; Kunukcu 2007), zeolite (Woinarski et al. 2003; Perić et al. 2004), activated carbon (Han et al. 2000; Fronczyk etal. 2010; Arora 2011) or organic carbon, e.g. compost and wood chips (Benner et al. 1997; Ludwig et al. 2009). An important part of design process of $\mathrm{PRB}$ is to choose the effective fillings of reactive zone. ZVI is considered as a potential reactive material for removal of numerous contaminants from groundwater (Roehl et al. 2005). The long-term performance of ZVI-PRB demonstrated to be a useful technology for treatment of the groundwater contaminated by chlorinated hydrocarbons (Alessi and Li 2001; Tratnyek et al. 2003; Kim et al. 2008), nitrates (Su and Puls 2004) and heavy metals (Diels et al. 2002; Moraci and Calabrň 2010). ZVI is strongly reducing material, 
what may lead to gases production $\left(\mathrm{H}_{2}\right.$ and $\mathrm{N}_{2}$ ) or precipitation of solids as hydroxides and salts such as carbonates (Henderson and Demond 2012) and in consequence to decrease of PRB permeability by reducing conductivity, porosity and iron reactivity. Some researchers have reported permeability losses up to two orders of magnitude in laboratory as well as in field scale (RTDF 2001; Mushovic et al. 2006; Henderson and Demond 2011). Moreover, the decrease of the reactive zone permeability may lead to the creation of favoured pathways outside the barrier causing the overflow of contaminated groundwater across the PRB. In consequence, the contaminants will remain mobile and pose a risk to the environment.

This paper presents the results of permeability test using Trautwein system and continuous column system. The aim of the experiments was to evaluate the influence of chemical substances (chloride, copper, lead, and mixture of cadmium, copper, nickel, lead, and zinc) on the hydraulic properties of reactive materials (ZVI and nZVI). Based on the test results, the possibility of ZVI and nZVI application as a reactive material in PRBs for groundwater protection along roads was analyzed.

\section{MATERIAL AND METHODS}

In this study, granular zero-valent iron (ZVI) and zero-valent iron powder (nZVI) were used as reactive material. nZVI was purchased from Hepure ${ }^{\mathrm{sm}}$ Technologies Inc, USA and ZVI from iPutec GmbH \& Co KG, Rheinfelden, Germany. The characteristic of reactive materials was presented in Table 1 .

TABLE 1. Characteristic of reactive materials

\begin{tabular}{|c|c|}
\hline Granulated zero-valent iron, ZVI & Zero-valent iron powder, nZVI \\
\hline $\begin{array}{l}\text { iPutec GmbH \& Co KG, Rheinfelden, Germany } \\
\text { manufacturer's declaration: } \\
\text { Product: Cast Iron Grit } \\
\text { Type: FG 0300/2000/ZVI } \\
\text { Particle distribution: } 300-2,000 \mu \mathrm{m} \text { (nominal) } \\
\text { Colour/shape: grey-black powder, needle shaped } \\
\text { particles } \\
\text { Density: } 6.7-7.2 \mathrm{~g} \cdot \mathrm{cm}^{-3} \\
\text { SBET: } 0.52 \mathrm{~m}^{2} / \mathrm{g}^{-1} \\
\text { Specific gravity: } 7.6 \\
\text { Chemical analysis, typical (\%): } \\
\text { Iron (Fe) } 92 \\
\text { Carbon (C) } 2.8-3.2 \\
\text { Silicon (Si) } 1.8-2.1 \\
\text { Phosphorous (P) } 0.04-0.4 \\
\text { Chrome (Cr) } 0.05-0.4 \\
\text { Nickel (Ni) } 0.05-0.3 \\
\text { Aluminum (Al) } 0.01-0.1\end{array}$ & $\begin{array}{l}\text { Hepure }^{\mathrm{sm}} \text { Technologies Inc, USA } \\
\text { manufacturer's declaration: } \\
\text { Product: Ferox-PRBTM ZVI Reactive Iron } \\
\text { Powder } \\
\text { Particle distribution: } 15-500 \mu \mathrm{m} \\
\text { Colour: grey-black powder } \\
\text { Density: } 2.92 \mathrm{~g} \cdot \mathrm{cm}^{-3} \\
\text { SBET: } 2.1 \mathrm{~m}^{2} \cdot \mathrm{g}^{-1} \\
\text { Specific gravity: } 7.8 \\
\text { Chemical composition }(\%) \text { : } \\
\text { Iron }(\mathrm{Fe}) \sim 95.0 \\
\text { Carbon }(\mathrm{C}) \sim 2.0 \\
\text { Oxygen }(\mathrm{O})<1.0 \\
\text { Silicon }(\mathrm{Si}) \sim 1.0 \\
\text { Phosphorous }(\mathrm{P}) \sim 2.0 \\
\text { Sulfur }(\mathrm{S}) \sim 0.1\end{array}$ \\
\hline
\end{tabular}


Moreover, a surface area and porosity analyzer (ASAP 2020M Micromeritics, USA), scanning electron microscope (SEM) images (FEG Quanta 250, USA) and X-ray diffraction (Philips X'Pert APD, Netherlands) spectra were used to detailed characterization of ZVI and nZVI particles.

All chemicals used for hydraulic test were of reagent grade (CHEMPUR, Poland). The concentration of reagents (5 $\mathrm{mg} \cdot \mathrm{L}^{-1}$ - hydraulic conductivity tests, and $20 \mathrm{mg} \cdot \mathrm{L}^{-1}$ - column test) were prepared using $\mathrm{NaCl}, \mathrm{CdCl}_{2} \cdot 2,5 \mathrm{H}_{2} \mathrm{O}$, $\mathrm{CuCl}_{2} \cdot 2 \mathrm{H}_{2} \mathrm{O}, \quad \mathrm{NiSO}_{4} \cdot 7 \mathrm{H}_{2} \mathrm{O}, \quad \mathrm{Pb}\left(\mathrm{NO}_{3}\right)_{2}$, and $\mathrm{ZnCl}_{2}$ in distilled water (DI). The $\mathrm{pH}$ of solutions was measured using $\mathrm{pH}$ meter (SCHOTT, Germany). In the tests with nZVI the $\mathrm{pH}$ of the chloride solution was in range 6.58-8.67 and the $\mathrm{pH}$ of the metal solution was between 1.66 and 4.30. Experiments with ZVI were carried out at different $\mathrm{pH}$ values: chloride solution in range 7.20-9.50 and metals solutions in range 7.60-8.40.

The hydraulic conductivity studies for ZVI and nZVI have been performed according to the standard ASTM D5084-00 (2001). During experiments constant - head tests ( " $i$ " $=2$ ) have been performed with flexible-wall permeameters of Trautwein system (Fronczyk and Garbulewski 2009). The desired hydraulic gradient was obtained by establishing an elevation difference between the liquid surface of inflow and outflow. The confining pressure was $3.6 \mathrm{psi}(25 \mathrm{kPa})$. The sample was $0.07 \mathrm{~m}$ in diameter and $0.11 \mathrm{~m}$ in height. The reactive materials were packed in 0.01-m-layers with density index of 0.6. On the bottom and on the top of samples the porous discs were used. At first, samples were permeated with distilled water until the constant hydraulic conductivity was achieved. Subsequently, the permeability test was continued using chemical solutions until equilibrium was established. The hydraulic conductivity of reactive materials permeated with water was conducted as a control for the studies using pollution. The hydraulic conductivity $(k)$ of samples, using constant head procedure, was calculated by measuring the volume of flow $(\Delta V)$ for given time interval $(\Delta t)$ :

$$
k=\frac{\Delta V}{A \cdot i \cdot \Delta t}
$$

where:

$A$ - cross-sectional area $\left(\mathrm{m}^{2}\right)$,

$i$ - hydraulic gradient (-), $\Delta t$ - time (s).

In graphical interpretation changes in hydraulic conductivity for chemical solutions $(k)$ in relation to hydraulic conductivity for distilled water $\left(k_{0}\right)$ were presented according to pore volume of flow $(P V F)$, which may be calculated using equation:

$$
P V F=\frac{k \cdot i \cdot t}{n \cdot L}
$$

where:

$n$ - porosity (-),

$L$ - length of the sample (m).

The continuous flow column test was conducted using 0.04-m-diameter and 0.5-m-length thick-walled poly(methyl methacrylate) - PMMA columns, fitted with Teflon threaded end fittings. The chemical solution from PCE container 
was flow through vinyl tubing into the column. The direction of solution flow was from bottom to top. The column was packed by small portion of ZVI in 0.01 -m-layers with density index of 0.6. On the bottom and on the top of samples the granular glass filter was used. The sample was permeated with distilled water until the constant hydraulic conductivity was achieved. The initial groundwater flow in column was $4 \cdot 10^{-8} \mathrm{~m}^{3} \cdot \mathrm{s}^{-1}$. The experiments were performed with chloride solution and multi-component solution of heavy metals $(\mathrm{Cd}, \mathrm{Cu}, \mathrm{Ni}$, $\mathrm{Pb}$, and $\mathrm{Zn}$ ). During test the hydraulic conductivity was determined using the constant-head permeability method and calculated using equation (1). The YSI Professional Plus(USA) multiparameter meter was used to measure $\mathrm{pH}$, ORP and temperature. All permeability tests were conducted at room temperature $\left(21.0 \pm 0.5^{\circ} \mathrm{C}\right)$.

\section{RESULTS AND DISCUSSION}

Figure 1 presents the XRD pattern of nZVI and energy-dispersive X-ray (EDX) mapping of ZVI samples. X-ray diffraction analysis was performed using XRD analysis instruments (Philips X'Pert APD, Netherlands) and scanning analysis was performed using FEG Quanta 250, FEI. Pattern and increased values of background on XRD spectra of the nZVI sample show, that the dominant mineral component is iron. The $\mathrm{X}$-ray diffraction for ZVI was not able to obtain, because of oxidation processes wherefore the SEM analysis was used for graphic interpretation. The composition of sample was as follows: $\mathrm{Fe} 98.95 \%, \mathrm{SiO}_{2} 0.58 \%, \mathrm{C}_{2} \mathrm{O}$ $0.42 \%, \mathrm{Al}_{2} \mathrm{O}_{5} 0.03 \%$ and $\mathrm{MgO} 0.02 \%$. The structure of nZVI and ZVI surfaces is presented in Figure 2.

In Table 2 the main test conditions and results were listed. The changes in hydraulic conductivity of reactive materials are presented in Figures 3 and 4. The hydraulic conductivity of the nZVI and ZVI remained unchanged during test with chloride solution, while the nZVI progressively clogged during testing with lead solution. After the lead ions injection the low reduction of hydraulic conductivity was also observed in ZVI sample. In the end of the experiment the value of hydraulic conductivity was on
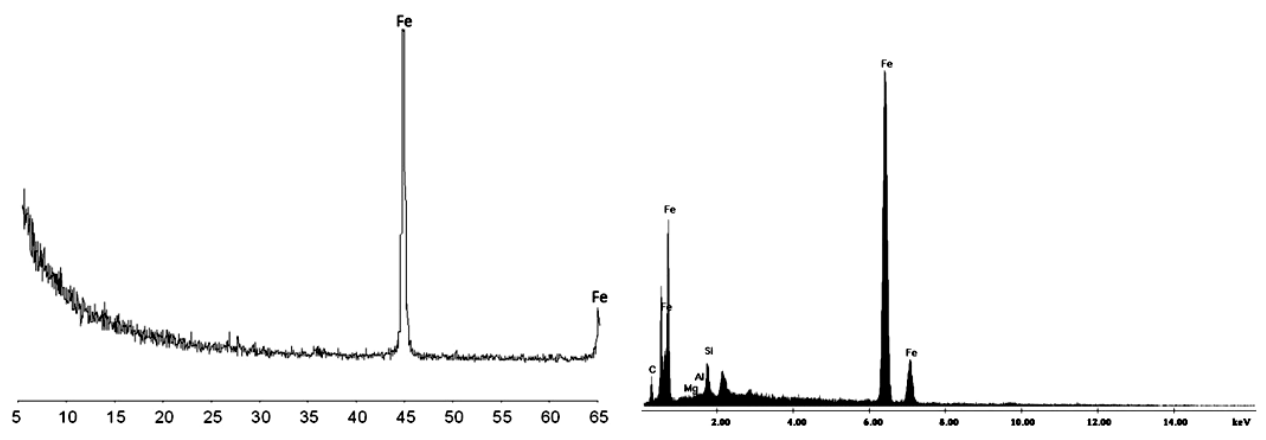

FIGURE 1. The XRD pattern of nZVI and EDX mapping of ZVI samples 


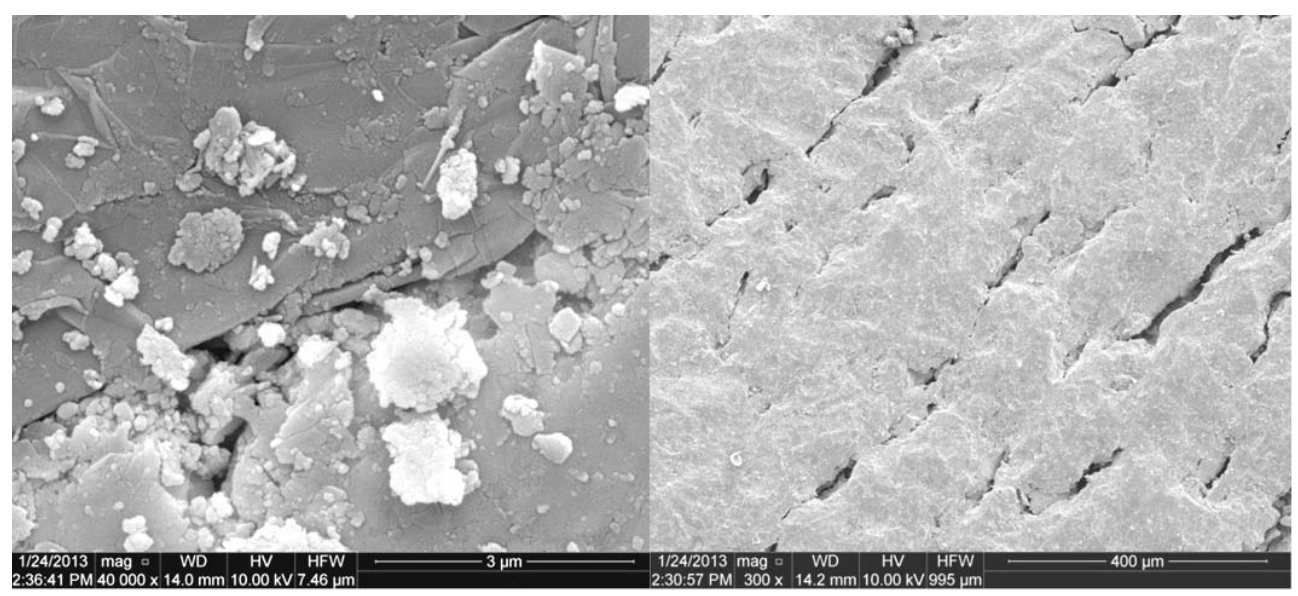

FIGURE 2. The SEM images of nZVI and ZVI samples

TABLE 2. The main permeability test conditions and results

\begin{tabular}{|l|c|c|c|c|c|}
\hline $\begin{array}{l}\text { Contaminated/ } \\
\text { Initial concetration } \\
\left(\mathrm{mg} \cdot \mathrm{L}^{-1}\right) / \text { Reactive } \\
\text { material }\end{array}$ & $\begin{array}{c}\text { Pore } \\
\text { volume } \\
(\mathrm{mL})\end{array}$ & $\begin{array}{c}\text { Test } \\
\text { duration } \\
(\mathrm{h})\end{array}$ & $\begin{array}{c}\text { Initial/Final } \\
\text { permeability } \\
\left(\mathrm{m} \cdot \mathrm{s}^{-1}\right)\end{array}$ & $\begin{array}{c}\text { Initial/final } \\
\mathrm{pH} \\
(-)\end{array}$ & $\begin{array}{c}\text { Initial/Final } \\
\text { ORP } \\
(\mathrm{mV})\end{array}$ \\
\hline $\mathrm{Cl} / 5 / \mathrm{nZVI}$ & 274.13 & 3.1 & $1.08 \cdot 10^{-4} / 1.08 \cdot 10^{-4}$ & $6.58 / 8.67$ & - \\
\hline $\mathrm{Cl} / 5 / \mathrm{ZVI}$ & 248.62 & 14.2 & $1.52 \cdot 10^{-4} / 1.39 \cdot 10^{-4}$ & $7.20 / 9.50$ & - \\
\hline $\mathrm{Cl} / 20 / \mathrm{ZVI}$ & 362.88 & 72.0 & $1.03 \cdot 10^{-4} / 1.01 \cdot 10^{-4}$ & $9.10 / 9.67$ & $96.4 / 21.6$ \\
\hline $\mathrm{Pb} / 5 / \mathrm{nZVI}$ & 274.13 & 7.1 & $1.08 \cdot 10^{-4} / 8.88 \cdot 10^{-5}$ & $1.66 / 4.30$ & - \\
\hline $\mathrm{Pb} / 5 / \mathrm{ZVI}$ & 248.62 & 11.7 & $1.52 \cdot 10^{-4} / 1.47 \cdot 10^{-4}$ & $7.60 / 8.40$ & - \\
\hline $\mathrm{Cu} / 5 / \mathrm{ZVI}$ & 248.62 & 15.3 & $1.52 \cdot 10^{-4} / 1.47 \cdot 10^{-4}$ & $7.60 / 8.42$ & - \\
\hline $\begin{array}{l}\mathrm{Cd}, \mathrm{Cu}, \mathrm{Ni}, \mathrm{Pb}, \mathrm{Zn}, \\
\mathrm{Cl} / 5 / \mathrm{ZVI}\end{array}$ & 248.62 & 12.0 & $1.52 \cdot 10^{-4} / 1.39 \cdot 10^{-4}$ & $7.61 / 8.32$ & - \\
\hline $\begin{array}{l}\mathrm{Cd}, \mathrm{Cu}, \mathrm{Ni}, \mathrm{Pb}, \mathrm{Zn}, \\
\mathrm{Cl} / 20 / \mathrm{ZVI}\end{array}$ & 362.88 & $1,320.0$ & $1.03 \cdot 10^{-4} / 1.51 \cdot 10^{-6}$ & $4.60 / 8.80$ & $96.4 /-22.8$ \\
\hline
\end{tabular}
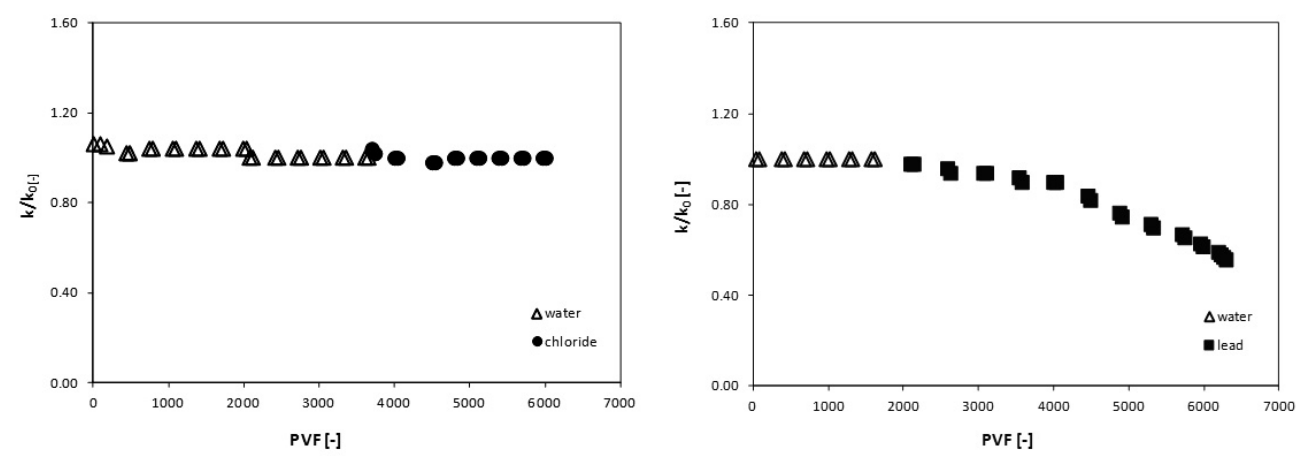

FIGURE 3. The impact of chloride and lead ions on hydraulic conductivity of nZVI 

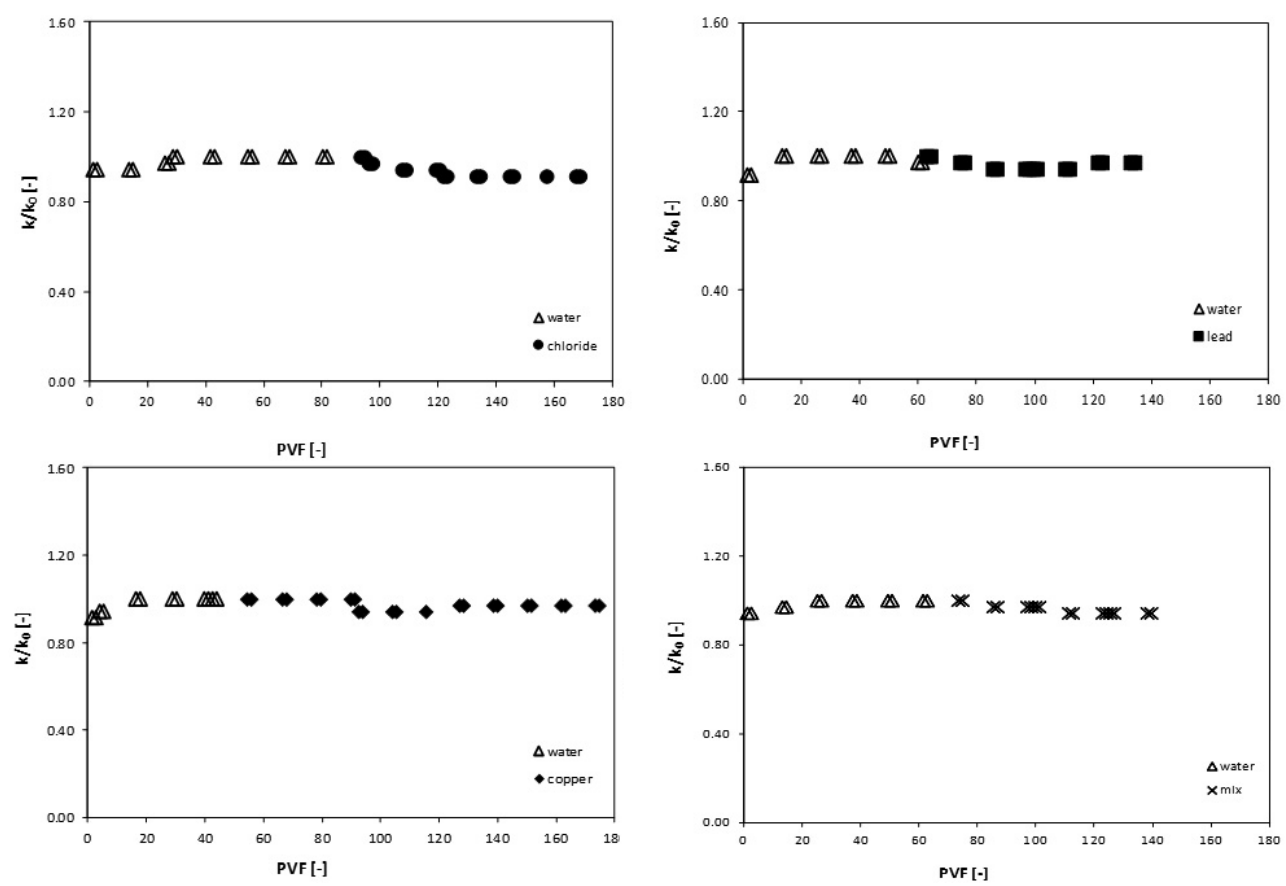

FIGURE 4. The impact of chloride, lead, copper and multi-component solution ions on hydraulic conductivity of ZVI

the same level as for test with distillated water. It may be due to the formation of alternative flow paths after progressive clogging of the reactive medium. At the end of experiment with lead solution, the presence of cemented part of nZVI core sample was observed. The form of precipitates implies that reduction is ongoing process.

In connection with the previously mentioned, the further test with nZVI was rejected. The experiments with copper and multi-component solutions were performed on the ZVI samples. The test results show low impact on value of hydraulic conductivity during copper and multi-component solution filtration by sample. Differences in the progress of hydraulic conductivity with time for lead, copper and multi-component are probably the result of differences in mass discharge and the different characteristics of the reaction products.

The experimental results obtained during column test carried out using the ZVI demonstrate change in hydraulic conductivity (Fig. 5). A permeability reduction of two orders of magnitude in column was observed (from $1.03 \cdot 10^{-4}$ to $\left.1.51 \cdot 10^{-6} \mathrm{~m} \cdot \mathrm{s}^{-1}\right)$. Moreover, six clogging of the reactive material were reported over the course of injection of: 267.15, $285.35,577.73,745.34,859.18$, and $1,450.43$ pore volumes of heavy metals solution. The increase in $\mathrm{pH}$ (from 4.6 to 8.8) and decrease in ORP (from 96.4 to $-22.8 \mathrm{mV}$ ) indicate the oxidation of ZVI. In such conditions, oxygen and water 

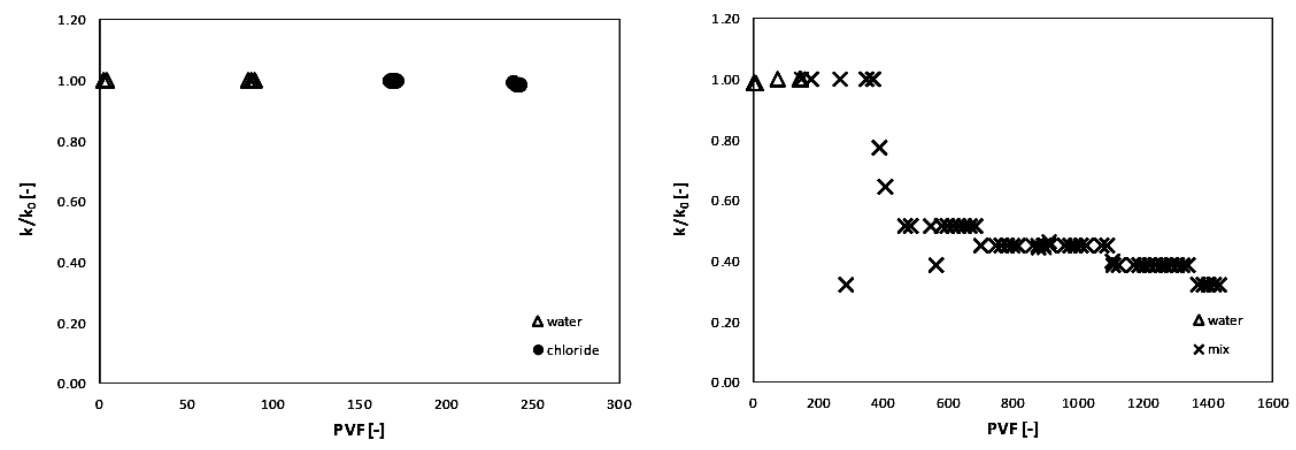

FIGURE 5. Column test - impact of chloride and multi-component solution ions on hydraulic conductivity of ZVI

may be reduced resulting in $\mathrm{H}_{2}$ formation (Henderson and Demond 2011). Davlin and Allin (2005) have suggested that nitrate, chloride and sulfate (that were present in multi-component solution of heavy metals) may inhibit the corrosion of ZVI. Moreover, the redox processes on zero-valent iron causes iron as well as heavy metals hydroxides precipitation, which may clog the reactive material and reduce the hydraulic conductivity. In consequence, solid formations have made the ZVI no longer available to treat the contaminated groundwater. On the other hand, the hydraulic conductivity of this column remained unchanged during experiment with chloride solution (from $1.03 \cdot 10^{-4}$ to $1.01 \cdot 10^{-4} \mathrm{~m} \cdot \mathrm{s}^{-1}$ ). Difference in the evolution of permeability for chlorides and heavy metals is probably the results of different removal pathways of these contaminants on ZVI.

The results clearly demonstrate that using pure ZVI in real PRB carry a risk of occur barrier for groundwater. Instead of using pure ZVI, a pretreatment buffer zone of sand or gravel with a small dose of ZVI (about 10\%) is recommended.
The buffer zone might be responsible for the dissolved oxygen removal and precipitates retained.

This phenomenon is undesirable particularly in the case of using this material to the construction of horizontal PRBs such as infiltration surface. If the permeability of PRB is too low or increase over the time, road runoffs will not infiltrate through it and will not be treated. Moreover, if overall hydraulic conductivity is not considerably reduced, the preferential flow paths in the reactive zone could be formed. In this instance most of the water will flow through favored flow paths and contact time may be too short to achieve expected treatment level. The use of horizontal PRB for the remediation of road runoffs is still at the very early stage of application.

\section{CONCLUSIONS}

The presented study allowed to draw the following conclusions:

- The hydraulic conductivity in all test remained practically unchanged during tests with chloride solutions. 
- During hydraulic conductivity studies the lead retention in the solution had no impact for hydraulic conductivity in ZVI sample, on the other hand the calculated hydraulic conductivity losses in nZVI samples were observed.

- The hydraulic conductivity studies demonstrate low impact on the value of hydraulic conductivity during copper, and multi-component solution filtration by ZVI. Differences in values of hydraulic conductivity with time for lead, copper and multi-component are seemed to be a difference in mass discharge and the different characteristics of the reaction products.

- A competition hydraulic conductivity studies exposed that the exploitation of ZVI is higher than the exploitation of nZVI.

- Long-term permeability test during column test showed the impact of mixtures of heavy metals on hydraulic conductivity decrease from $1.03 \cdot 10^{-4}$ to $1.51 \cdot 10^{-6} \mathrm{~m} \cdot \mathrm{s}^{-1}$.

- A several number of clogging of the reactive material caused by iron oxide-hydroxides precipitation was observed over the course of injection of heavy metals solution. The increase in $\mathrm{pH}$ and decrease in ORP confirm the occurrence of this process.

- In real PBR a pretreatment buffer zone of sand or gravel with a small dose of ZVI (about 10\%) is recommended before ZVI zone.

- Further investigation is necessary into the effect of buffer zone and other contaminants present in groundwater in vicinity of roads.

\section{Acknowledgements}

This research was supported by grant NN523 561638 from National Science Centre, Poland.

\section{REFERENCES}

ALESSI D.S., LI Z. 2001: Synergistic effect of cationic surfactants on perchloroethylene degradation by zero-valent iron. Environ. Sci. Technol. 35(18): 3713-3717.

ARORA M., SNAPE I., STEVENS G.W. 2011: The effect of temperature on toluene sorption by granular activated carbon and its use in permeable reactive barriers in cold regions. Cold Reg. Sci. Technol. 66(1): 12-16.

American Society for Testing and Materials (ASTM) D5084-00. 2001: Standard Test Methods for Measurement of Hydraulic Conductivity of Saturated Porous Materials Using a Flexible Wall Permeameter.

BENNER S.G., BLOWES D.W., PTACEK C.J. 1997: A full scale-porous reactive wall for prevention of acid mine drainage. Ground Water Monit. Rem. 17: 99-107.

DAVLIN J.F., ALLIN K.O. 2005: Major anion effects on the kinetics and reactivity of granular iron in glass-encased magnet batch reactor experiments. Environ. Sci. Technol. 39(6): 1868-1874.

DIELS L., Van Der LELIE N., BASTIAENS L. 2002: New developments in treatment of heavy metal contaminated soils. Rev. Environ. Sci. Biotechnol. 1(1): 75-82.

DRIES J., BASTIAENS L., SPRINGAEL D., AGATHOS S.A., DIELS L. 2005: Combined removal of chlorinated ethanes and heavy metals by zerovalent iron in batch and continuous flow column systems. Environ. Sci. Technol. 39: 8460-8465.

FRONCZYK J., GARBULEWSKI K. 2009: Selection of material suitable for permeable reactive barriers in the vicinity of landfills. Ann. Warsaw Univ. of Life Sci. - SGGW, Land Reclam. 41: 3-9.

FRONCZYK J., PAWLUK K., MICHNIAK M. 2010: Application of permeable reactive barriers near roads for chloride ions removal. 
Ann. Warsaw Univ. of Life Sci. - SGGW, Land Reclam. 42: 249-259.

GAVASKAR A., GUPTA N., SASS B., JANOSY R., HICKS J. 2000: Design Guidance for Application of Permeable Reactive Barriers for Groundwater Remediation. Battelle, Columbus, Ohio.

HAN I., SCHLAUTMAN M.A., BATCHELOR B. 2000: Removal of Hexavalent Chromium from Groundwater by Granular Activated Carbon. Water Environ. Res. 72(1): 29-39.

HENDERSON A.D., DEMOND A.H. 2011: Impact of solids formation and gas production on the permeability of ZVI PRBs. J. Environ. Eng. 137: 689-696.

HENDERSON A.D., DEMOND A.H. 2012: Permeability of iron sulfide (FeS)-based materials for groundwater remediation. Water Res. 47: 1267-1276.

JOHNSON R.L., THOMS R.B., O'BRIEN JOHNSON R., KRUG T. 2008: Field evidence for flow reduction through a zero-valent iron permeable reactive barrier. Ground Water Monit. Rem. 28(3): 47-55.

KAO C.M., CHEN S.C., SU M.C. 2001: Laboratory column studies for evaluating a barrier system for providing oxygen and substrate for TCE biodegradation. Chemosphere 44: 925-934.

KIM H., HONG H.J., LEE Y.J., SHIN H.J., YANG J.W: 2008. Degradation of trichloroethylene by zero-valent iron immobilized in cationic exchange membrane. Desalination 223(1-3): 212-220.

KUNUKCU Y.K. 2007: In situ bioremediation of groundwater contaminated with petroleum constituents using oxygen release compounds (ORCs). J. Environ. Sci. Health., Part A 42(7): 839-845.

LUDWIG R.D., SMYTH D.J.A., BLOWES D.W., SPINK L., WILKIN R.T., JEWETT D.G., WEISENER C.J. 2009: Treatment of arsenic, heavy metals, and acidity using a mixed zvi-compost PRB. Environ. Sci. Technol. 43(6): 1970-1976.

MORACI N., CALABRŇ P.S. 2010: Heavy metals removal and hydraulic performance in zero-valent iron/pumice permeable reactive barriers. J. Environ. Manage. 91(11): 2336-2341.
MUSHOVIC P., BARTLETT T.R., MORRISON S. 2006: Hydraulic conductivity loss at the Monticello PRB leads to trial use of ex-situ treatment cell. Technology News \& Trends 23: 1-3.

PERIĆ J., TRGO M., VUKOJEVIĆ MEDVIDOVIĆN. 2004: Removal of zinc, copper and lead by natural zeolite - a comparison of adsorption isotherms. Water Res. 38: 1893-1899.

ROEHL K.E., CZURDA K., MEGGYES T., SIMON F., STEWART D.I. 2005: Long-term performance of permeable reactive barriers. Elsevier, USA.

Remediation Technologies Development Forum (RTDF). 2001: Permeable Reactive Barrier Installation Profiles. http://www.rtdf.org/public/ permbarr/prbsumms/ (Accessed 10.01.2013).

SU C.M., PULS R.W. 2004: Nitrate reduction by zero-valent iron: effects of formate, oxalate, citrate, chloride, sulfate, borate, and phosphate. Environ. Sci. Technol. 38: 2715-2720.

TRATNYEK P.G., SCHERER M.M., JOHNSON T.L., MATHESON L.J. 2003: Permeable reactive barriers of iron and other zero-valent metals. In: M.A. Tarr [Ed.]. Chemical degradation methods for wastes and pollutants: Environmental and industrial application. Marcel Dekker, New York: 371-421.

WOINARSKI A.Z., SNAPE I., STEVENS G.W., STARK S.C. 2003: The effects of cold temperature on copper ion exchange by natural zeolite for use in a permeable reactive barrier in Antarctica. Cold Reg. Sci. Technol. 37(2): 159-168.

Streszczenie: Właściwości filtracyjne przepuszczalnych barier reaktywnych zbudowanych $z$ żelaza zero-wartościowego i nano-żelaza zero-wartościowego - badania laboratoryjne. Produkcja gazów oraz wytrącanie się nierozpuszczalnych cząstek stałych może być przyczyną zmian współczynnika filtracji przepuszczalnych barier reaktywnych PBR wykonanych z żelaza zero-wartościowego (ZVI). Zmiany te mogą być przyczyną nieprawidłowego przebiegu procesów oczyszczania środowiska gruntowo-wodnego. $\mathrm{W}$ artykule przedstawiono wyniki laboratoryjnych badań przepuszczalności hydraulicznej mających na celu sprawdzenie wpływu chlorków 
i metali ciężkich $(\mathrm{Cd}, \mathrm{Cu}, \mathrm{Ni}, \mathrm{Pb}, \mathrm{Zn})$ na wartość współczynnika filtracji $(k)$ wybranych materiałów reaktywnych - ZVI i nZVI. Analiza uzyskanych wyników badań wykazała brak wpływu chlorków oraz jonów ołowiu na współczynnik filtracji ZVI $\left(k=1,03 \cdot 10^{-4} \mathrm{~m} \cdot \mathrm{s}^{-1}\right)$. Obecność $\mathrm{Pb}(\mathrm{II}) \mathrm{w}$ roztworze spowodowała natomiast znaczące zmniejszenie wartości $k$ nZVIz $4,10 \cdot 10^{-5} \mathrm{do} 2,30 \cdot 10^{-5} \mathrm{~m} \cdot \mathrm{s}^{-1}$. Przepływ roztworu zawierającego mieszaninę metali ciężkich przez próbkę ZVI również spowodował zmniejszenie zdolności filtracyjnych materiału, co mogło być spowodowane intensywnie zachodzącymi procesami redukcji materiału. Współczynnik filtracji podczas trwania badania zmniejszył się $\mathrm{z}$ wartości $1,03 \cdot 10^{-4}$ do $1,51 \cdot 10^{-6} \mathrm{~m} \cdot \mathrm{s}^{-1}$. Podczas filtracji roztworu mieszaniny metali ciężkich przez kolumny wypełnione ZVI zaobserwowano kolmatację materiału spowodowaną wytracaniem się wodorotlenków żelaza i metali ciężkich, czemu towarzyszyło zwiększenie odczynu oraz zmniejszenie potencjału oksydacyjno-redukcyjnego roztworu wypływającego z kolumny. Zaprezentowane w artykule wyniki badań wskazują na konieczność uwzględnienia podczas projektowania PBR wpływu zanieczyszczeń na zmiany właściwości filtracyjnych materiałów reaktywnych.

Stowa kluczowe: przepuszczalne bariery reaktywne, przepuszczalność hydrauliczna, żelazo zero-wartościowe, nano-żelazo zero-wartościowe

MS. received in February 2014

\section{Authors' address:}

Joanna Fronczyk, Katarzyna Pawluk

Zakład Geotechniki, Katedra Geoinżynierii

Wydział Inżynierii i Kształtowania Środowiska, SGGW

02-776 Warszawa, ul. Nowoursynowska 159

Poland

e-mail: joanna_fronczyk@sggw.pl 